\title{
Актуалізація та шляхи підвищення рівня культури праці в Україні
}

\author{
Андрій Бочковський ${ }^{*}$; Наталя Сапожнікова А \\ А Одеський національний політехнічний університет, проспект Шевченка, 1, м. Одеса, 65044, Україна
}

Received: July 10, 2020 | Revised: August 16, 2020 | Accepted: August 31, 2020

DOI: $10.33445 /$ sds.2020.10.4.4

\begin{abstract}
Анотація
Встановлено, що за період з 2010 року по 2014 рік (період дії наказу № 969/922/216) кількість нещасних випадків за організаційними причинами (що характеризують саме рівень культури праці) знизилась на 16,3\%. При цьому, найбільш активне зниження спостерігалося за період з 2011 по 2012 роки (на 10\%). За період з 2007 по 2011 роки (до введення в дію наказу), а також за період з 2014 по 2019 роки (скасування дії наказу), аналогічні показники зросли на 2,5\% та 3,1\% відповідно, що свідчить про необхідність спрямування зусиль на реформування системи підготовки та навчання фахівців з питань охорони праці та розробки заходів щодо посилення мотивації на підприємствах щодо неухильного виконання ними вимог нормативно-правових актів 3 охорони праці. Основними проблемами системи підготовки майбутніх фахівців з питань охорони праці у ЗВО України є: загальний характер змісту та суті існуючої «безпекової» компетентності (з охорони праці) у стандартах освіти, що призводить до формалізації процесу навчання студентів з питань охорони праці за рахунок злиття різнопланових дисциплін, зменшення навчальних годин на їх опанування, зміна форм контролю знань студентів з іспиту на залік, а також виведення відповідних дисциплін у розряд вибіркових, наслідком чого $\epsilon$ процес їх фактичного знищення; відсутність «безпекової» компетенції у 68\% стандартах освіти; відсутність стандартів освіти для 44\% спеціальностей підготовки майбутніх фахівців. Основними шляхами підвищення рівня культури праці в Україні $є$ : поновлення чинності наказу № 969/922/216, який дозволить конкретизувати вимоги компетентності «здійснення безпечної діяльності» для стандартів освіти за принципом «від загального до конкретного»; розробка математичних моделей для встановлення об'єктивних залежностей між якісними характеристиками навчального матеріалу та психофізіологічними можливостями людини до його засвоєння протягом певного часу на основі положень відомих психофізіологічних законів; включення до характеристик відповідності кваліфікації викладача за видами і результатами професійної діяльності (згідно з «Ліцензійними умовами провадження освітньої діяльності») положення щодо обов'язкової відповідності профільної освіти або наукового ступеня та тематики наукових праць викладача профілю кафедри та дисциплін, які він викладає; забезпечення всіх без виключення спеціальностей стандартами освіти, в рамках яких буде враховано вимоги наказу № 969/922/216; перехід системи соціального страхування України від існуючої концепції сплати єдиного соціального внеску до концепції диференційованого підходу сплати такого внеску відносно рівня ризику виникнення професійних небезпек по кожному робочому місцю. Обгрунтовано актуальність та розроблено шляхи підвищення рівня культури праці в Україні. Результати досліджень будуть використані як аналітична та теоретична база для розробки наукових основ мінімізації проявів «людського фактора» в сфері охорони праці.
\end{abstract}

\footnotetext{
* Corresponding author: Одеський національний політехнічний університет, д.т.н., доцент, професор кафедри управління системами безпеки життєдіяльності, e-mail: andrew.bochkovsky@gmail.com, ORCID: http://orcid.org/0000-0002-4166-3148
} 
Ключові слова: охорона праці, культура праці, система освіти, професійна небезпека, «людський фактор».

\section{Постановка проблеми}

Основною метою функціонування сучасних систем управління охороною праці на підприємствах (СУОПП) є попередження виникнення нещасних випадків, професійних захворювань, а також промислових аварій та катастроф (Закон України «Про охорону праці»). Для досягнення зазначеної мети необхідно чітко розуміти причини їх виникнення та розробити і вжити заходи i засоби щодо їх усунення (Bochkovskyi A. Р., Sapozhnikova, 2015).

На сьогоднішній день, офіційна статистика в Україні розглядає три основні види причин виникнення нещасних випадків організаційні, психофізіологічні та технічні (Аналіз страхових нещасних випадків та професійних захворювань в Україні в 2007 2016 рр., Профілактика виробничого травматизму та професійних захворювань за 2017-2019 рр.). До організаційних причин відносять невиконання вимог інструкцій 3 охорони праці, посадових інструкцій, порушення технологічного процесу та інші. До основних психофізіологічних травмування або смертельні випадки внаслідок протиправних дій інших осіб, помилкові дії внаслідок втоми працівника через надмірну важкість і напруженість роботи; монотонність праці; хворобливий стан працівника; необережність; невідповідність психофізіологічних чи антропометричних даних працівника техніці, що використовується чи роботі, що виконується; незадоволення роботою; несприятливий психологічний мікроклімат у колективі, до технічних - незадовільний технічний стан виробничих об'єктів, будинків, споруд, інженерних комунікацій, території (Аналіз страхових нещасних випадків та професійних захворювань в Україні в 2007 2016 рр., Профілактика виробничого травматизму та професійних захворювань за 2017-2019 рр.). Поєднує зазначені причини те, що всі вони пов'язані з певними діями або бездіяльністю людини (проявами «людського фактора»), внаслідок чого і стався певний нещасний випадок (Бочковський А. П., дис., 2019). Також аналіз причин виникнення інших небезпек - професійних захворювань, промислових аварій і катастроф, дозволяє зробити висновок, що вони теж пов'язані 3 певними проявами «людського фактора» (Бочковський А. П., дис., 2019; Бочковський А.П., монографія, 2015).

Так, наприклад, професійне захворювання може бути наслідком, як бездіяльності керівництва підприємства щодо створення належних умов праці, так і наслідком недбалого ставлення працівника до вимог інструкцій з охорони праці. А промислова аварія теж $€$ наслідком відповідних порушень, як з боку керівництва підприємства, так і з боку працівника (Бочковський А. П., дис., 2019; Бочковський А.П., монографія, 2015; Бочковський, 2016).

Таким чином, для можливості попередження виникнення проявів «людського фактора», необхідно зрозуміти причини, що спонукають працівника (керівника) до дій або бездіяльності, що призвели до реалізації професійної небезпеки. Незважаючи на різноманітний характер проявів «людського фактора», загальні причини їх виникнення можна умовно розділити на три основні групи. Перша з них пов'язана з низьким рівнем культури праці (зокрема низьким рівнем знань нормативно-правових документів 3 охорони праці), друга - 3 низькою якістю нормативно-правового забезпечення в галузі охорони праці, третя - з психофізіологічними реакціями працівника на вплив зовнішнього середовища, а також процесів, що відбуваються в його організмі.

Зважаючи на досить складний характер 


\begin{tabular}{llrlrc}
\hline проблематики мінімізації & проявів & обмежитися & розробкою & шляхів, & що \\
«людського фактора» в сфері охорони праці, & стосуються & попередження & виникнення \\
в рамках дослідження $\in$ & доцільним & причин, які відносяться до першої групи.
\end{tabular}

\section{Аналіз останніх досліджень та публікацій}

Обґрунтуванню актуальності та розробці шляхів підвищення рівня культури праці в Україні було присвячено наступні наукові праці.

Так, в роботі (Zhurbynskyi D., Tarasenko A., 2018) проведено аналіз ситуації у сфері безпеки, що склалася в Україні під впливом сучасних динамічних процесів та визначено основні проблемні питання, які пов'язані зі зниженням рівня культури безпеки громадян у зв'язку із різким зростанням ризиків виникнення надзвичайних ситуацій природного, техногенного і соціальнополітичного походження. Підкреслено важливість безпекових дисциплін, як необхідної складової сучасного освітнього процесу та запропоновано шляхи формування нового світогляду, системи ідеалів і цінностей, тобто формування цілісної культури безпеки в процесі професійної підготовки майбутнього фахівця.

Дослідники у роботі (Романюк Р. Я., Крюковська О.А., 2019) відмічають негативні тенденції, щодо виключення 3 програм підготовки «бакалаврів» та «магістрів» дисциплін «Безпека життєдіяльності», «Основи охорони праці», «Охорона праці в галузі» та «Цивільний захист», а також відповідних розділів з їх випускних робіт. І хоча, спираючись на результати аналізу законодавства України щодо обов'язковості викладання у закладах вищої освіти зазначених дисциплін, авторами показано неприпустимість таких дій (порушує законодавство України), вказані тенденції спостерігаються в Україні протягом останніх років. В роботі підкреслено актуальність забезпечення майбутніх фахівців знаннями, уміннями і навичками здійснення безпечної професійної діяльності.

В роботі (Кобилянський О., Заюков І., Пінаєва О., 2018) розглянуто актуальність підвищення рівня промислової безпеки зайнятих громадян та підкреслено важливість постійного оновлення та розвитку знань 3 питань охорони праці та промислової безпеки, оскільки саме від цього залежить ступінь безпеки працівників. Вирішення зазначеної проблеми, на думку авторів роботи, можливе за рахунок переходу до концепції безперервної освіти, зокрема її основної складової самоосвіти (інформальної освіти). Визначено концептуальну основу інформальної освіти в системі підвищення рівня знань з промислової безпеки, яка має входити в усі етапи професійного розвитку працівників (професійне навчання, перенавчання, підвищення кваліфікації, особистий розвиток, тощо), що дозволить їм набувати нових компетенцій та в цілому підвищувати загальний рівень компетентності.

В роботі (Поведа Т. П., 2017) висвітлено проблему підготовки майбутніх фахівців 3 питань безпеки в умовах реформування вищої освіти в Україні, проаналізовано причини негативної тенденції, яка склалася останнім часом з викладанням дисциплін безпекового циклу. Обґрунтовано необхідність і обов'язковість безперервного навчання зазначених дисциплін під час підготовки «бакалаврів» та «магістрів» усіх спеціальностей у закладах вищої освіти. Значну увагу приділено питанням модернізації підходів до викладання дисциплін з безпеки та охорони праці. Окреслено перспективи освіти з безпеки, модернізації її змісту відповідно до нагальних потреб безпеки сучасного суспільства.

В роботі (Гвоздій С.П., 2017) автор зазначає, що постійно зростаючий рівень природних і техногенних небезпек, ризики в буденному житті та в професійній діяльності вимагають нової орієнтації системи вищої освіти України щодо якості підготовки майбутніх фахівців 3 питань безпеки. А приєднання України до Концепції ООН «Про сталий людський розвиток» зумовлюють потребу суттєвих змін в усіх ланках системи забезпечення безпеки житя і діяльності людини, зокрема оновлення 
змісту освіти щодо безпеки життя та діяльності людини, модернізації форм і методів його опанування. 3 цією метою, автором розроблено діагностувальну й експериментальну методики підготовки майбутніх фахівців соціономічних спеціальностей до безпеки життя і професійної діяльності, а також запропоновано сучасне методичне забезпечення нормативних дисциплін «Безпека житєдіяльності», «Основи охорони праці».

\section{Постановка завдання}

Метою даної роботи $€$ обгрунтування актуальності та розробка шляхів підвищення рівня культури праці в Україні.

Досягнення зазначеної мети передбачається в процесі вирішення наступних завдань:

- проаналізувати динаміку змін кількості нещасних випадків на підприємствах України в
Однак аналіз зазначених досліджень виявив низку невирішених проблем, які полягають у необхідності встановлення обґрунтованих взаємозв'язків між рівнем знань людини у сфері охорони праці та культурою праці, а також розробки шляхів їх підвищення, що дозволить в подальшому попереджувати виникнення нещасних випадків, професійних захворювань, а також промислових аварій $\mathrm{i}$ катастроф, причинами яких $€$ певні прояви «людського фактора».

\section{Виклад основного матеріалу}

Проблематику мінімізації проявів «людського фактора» в контексті підвищення рівня культури праці необхідно розглядати в розрізі трьох основних аспектів, що стосуються формування у працівника (керівника підприємства) необхідного рівня знань з питань охорони праці, мотивації (як працівника, так і керівника) до неухильного дотримання вимог відповідних нормативно-правових актів, а також забезпечення функціонування ефективної системи контролю за дотриманням норм та правил з охорони праці на робочих місцях.

При цьому під необхідним рівнем знань розуміється не просто «прослуховування» майбутнім фахівцем певного навчального курсу у закладі освіти (працівником або керівником підприємства програми навчання у відповідних навчально-методичних центрах), а формування у свідомості людини принципу «пріоритету власної та колективної безпеки» в умовах виконання виробничої діяльності. Це, зокрема, необхідно з огляду на необхідність реалізації третьої статті Конституції України «Людина, її життя і здоров'я, честь і гідність, недоторканність і безпека визнаються в Україні найвищою соціальною цінністю». контексті особливостей реформування системи вищої освіти;

- визначити основні проблеми підготовки фахівців з питань охорони праці у закладах вищої освіти України;

- розробити шляхи підвищення рівня культури праці в Україні.
Під мотивацією слід розуміти впровадження на підприємствах системи фінансових заохочень та штрафів для працівників, а також створення та забезпечення функціонування на державному рівні прогресивної, ризикорієнтовної системи соціального захисту працівників.

Під ефективною системою контролю розуміється наступна трирівнева система. На першому рівні контроль здійснюється працівником - шляхом проведення самоконтролю відповідності умов праці на робочому місці вимогам нормативно-правових актів та інструкцій з охорони праці. На другому рівні - відповідний контроль по кожному робочому місцю здійснюється керівною ланкою підприємства. I нарешті, загальний контроль за безпекою праці здійснюється на третьому рівні - державними контролюючими органами. В цьому випадку прослідковується прямий взаємозв'язок між мотивацією працівника і керівника до дотримання ними вимог нормативно-правових актів з охорони праці та ефективністю системи контролю за безпекою праці на підприємстві на перших двох рівнях. 
Важливим кроком на шляху формування у майбутніх фахівців принципу «пріоритету безпеки» став спільний наказ Міністерства освіти і науки України, Міністерства 3 надзвичайних ситуацій, а також Держгірпромнагляду України від 21.10.2010 р. № 969/922/216. Згідно з наказом, у закладах вищої освіти встановлювався перелік обов'язкових до вивчення всіма студентами (незалежно від спеціальності та форми навчання) дисциплін у сфері безпеки житєдіяльності, охорони праці та цивільного захисту населення в умовах надзвичайних ситуацій. Для зазначених дисциплін встановлювалася мінімальна кількість годин на їх опанування, а також форми підсумкового контролю знань у вигляді іспитів та диференційованого заліку (для дисципліни «Цивільний захист»). На виконання наказу також вводилися у дію типові навчальні програми з відповідних дисциплін. Основною позитивною рисою таких заходів можна вважати впровадження так званого принципу гарантованої програми підготовки фахівців 3 питань охорони праці. Тобто, який би заклад вищої освіти не закінчував молодий фахівець, роботодавець міг гарантовано розраховувати на певний «базовий» рівень його підготовки 3 питань охорони праці (Наказ № 969/922/216; Bochkovskyi A. P., Sapozhnikova N. Yu., Gogunskii V. D., 2017; Bochkovskyi A. P., Sapozhnikova N. Yu., Gogunskii V. D., 2016).

Однак, позитивний ефект від впровадження вимог наказу дещо нівелювався практичною відсутністю нормативно-правового підґрунтя щодо мотивації працівників та керівників підприємств до дотримання ними норм та правил з охорони праці на робочих місцях. Так, система штрафів та заохочень працівників хоча і мала місце бути на окремих підприємствах, але її ефективність була сумнівною, оскільки залежала лише від свідомості роботодавця, а не від його мотивації з боку держави щодо створення належних умов праці. Зазначена мотивація з боку держави обмежувалася лише відповідальністю роботодавця за виявлені порушення під час перевірок наглядовими органами або у разі настання нещасного випадку. Проте, порівняно невеликий розмір штрафів за певні порушення i існуюча проблема певних «домовленостей» у разі порушень значно знижувала та знижує ефективність зазначеної мотивації.

Однак, не зважаючи на зазначені проблеми, аналіз статистичних даних, за період з 2011 року по 2014 рік (рік припинення дії наказу № 969/922/216 та введення мораторію на перевірки підприємств наглядовими органами зокрема $з$ охорони праці) свідчить про позитивну динаміку зниження кількості нещасних випадків за організаційними причинами (що характеризують саме рівень культури праці) на $16,3 \%$ (рис. 1) (Аналіз страхових нещасних випадків та професійних захворювань в Україні в 2007 - 2016 рр., Профілактика виробничого травматизму та професійних захворювань за 2017-2019рр.; Бочковський А.П., Сапожнікова Н.Ю., 2017). Якщо проаналізувати відповідні дані за попередні роки (до введення в дію наказу), то можна спостерігати динаміку зростання кількості нещасних випадків на 2,5\% (за період з 2007 по 2011 роки), а також різке зниження зазначених показників (після введення в дію наказу) за період 2011 - 2012 роки на $10 \%$ (рис. 1) (Аналіз страхових нещасних випадків та професійних захворювань в Україні в 2007 2016 рр., Профілактика виробничого травматизму та професійних захворювань за 2017-2019 рр.; Бочковський А.П., Сапожнікова Н.Ю., 2017). Остання цифра, як і позитивна тенденція 2011 - 2014 років, хоча і опосередковано, але доводить ефективність впровадження відповідних змін у систему освіти.

Однак, у 2014 році, разом з прийнятям Закону України «Про вищу освіту» (згідно вимог якого фактично було ліквідовано типові програми з відповідних навчальних дисциплін), наказ № 969/922/216 було скасовано (розпорядження КМУ від 30.05.2014 року №590-р), окрім того було запроваджено мораторій на перевірки підприємств, зокрема державними наглядовими органами з охорони праці (діяв до 2018 року). 


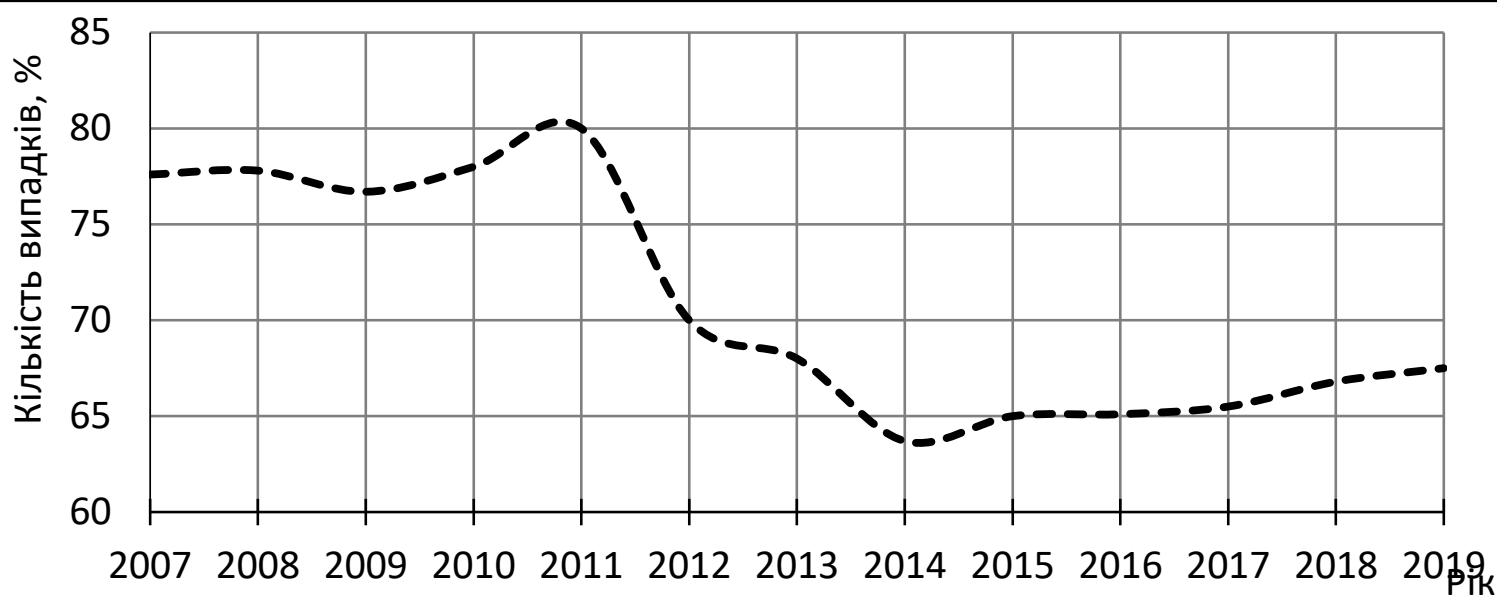

Мал. 1 - Динаміка зміни кількості нещасних випадків за організаційними причинами в Україні по роках

Якщо проаналізувати відповідні статистичні дані за цей період (тобто з 2014 по 2019 роки), то можна зробити висновок, що, незважаючи на скорочення кількості зареєстрованих робочих місць (більше ніж на $10 \%$ (рис. 2)), кількість зареєстрованих нещасних випадків, що сталися за організаційними причинами, збільшилася на 3,1\% (рис. 1) (Аналіз страхових нещасних випадків та професійних захворювань в Україні в 2007 - 2016 рр., Профілактика виробничого травматизму та професійних захворювань за 2017-2019рр.; Бочковський А.П., Сапожнікова Н.Ю., 2017).

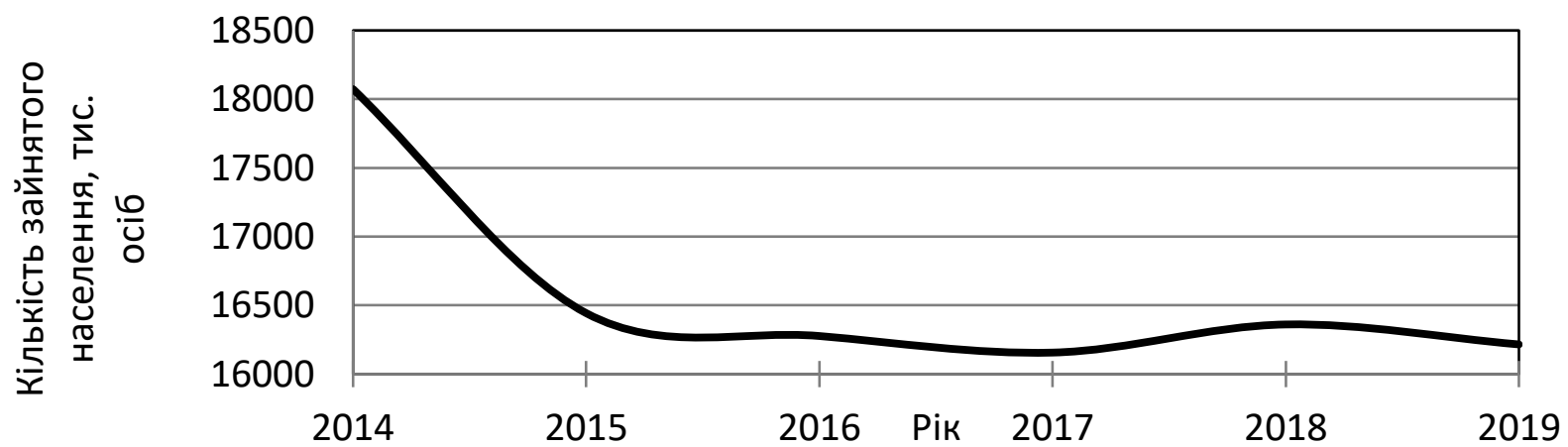

Мал. 2 - Динаміка зміни кількості зайнятого населення України по роках

При цьому, в структурі організаційних причин спостерігається стійка тенденція щодо поступового зростання нещасних випадків, які пов'язані з невиконанням інструкцій з охорони праці (на 5,4\% тільки за останні три роки (рис. 3)), що свідчить про посилення зневажливого ставлення працівників та керівників підприємств до вимог 3 охорони праці. Помітно, що за період з 2011 по 2014 роки відповідний показник на підприємствах України зменшився на 9,5\% (рис. 3) (Аналіз страхових нещасних випадків та професійних захворювань в Україні в 2007 - 2016 рр., Профілактика виробничого травматизму та професійних захворювань за 2017-2019рр.;
Бочковський А.П., Сапожнікова Н.Ю., 2017).

Таким чином, виходячи 3 наведених результатів аналізу статистичних даних та враховуючи, що, незважаючи на знятя мораторію на перевірки, динаміка кількості нещасних випадків за організаційними причинами $є$ негативною. Отже можна зробити висновок щодо необхідності спрямування зусиль на реформування саме системи підготовки та навчання фахівців різних галузей з питань охорони праці та розробки заходів щодо посилення мотивації на підприємствах до неухильного виконання ними вимог нормативно-правових актів з охорони праці. 


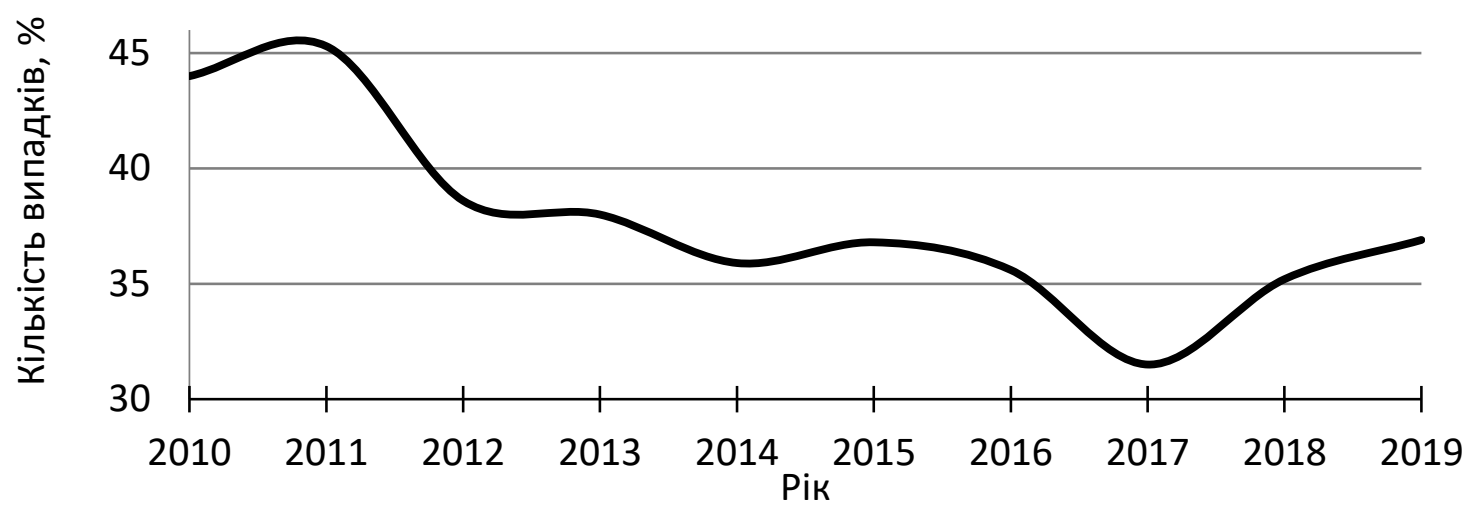

Мал. 3 - Динаміка зміни кількості нещасних випадків, які пов'язані з невиконанням інструкцій з охорони праці в Україні по роках

На сьогоднішній день, згідно з Законом «Про вищу освіту», заклади вищої освіти України (ЗВО) самостійно встановлюють номенклатуру та обсяг навчальних дисциплін, зокрема з питань охорони праці, спираючись на стандарти вищої освіти. Зазначені стандарти розробляються Науково-методичною радою Міністерства освіти і науки України (МOH) для кожної спеціальності та погоджуються 3 Національною агенцією із забезпечення якості вищої освіти (НАЗЯВО). Стандарти зокрема визначають обсяг кредитів ЄКТС (загальну кількість годин на вивчення дисциплін), перелік обов'язкових компетентностей випускника, форму атестації здобувачів та інше. В такому випадку сучасна освітня підготовка майбутніх фахівців 3 питань охорони праці характеризується наступними основними проблемами.

Перша з них пов'язана з тим, що серед 31 рекомендованих для стандартів освіти компетентностей лише одна (формально) відноситься до сфери охорони праці «здійснення безпечної діяльності» (Методичні рекомендації щодо розробки стандартів вищої освіти, 2019 р.). Як видно, загальний характер зазначеної компетентності створює передумови встановлення ЗВО номенклатури відповідних дисциплін на власний розсуд. На практиці це призводить до того, що студентам пропонуються до вивчення в одному блоці різнопланові дисципліни, наприклад, цивільний захист та охорона праці в галузі, безпека житєдіяльності та основи охорони праці. Метою цього $€$ перерозподіл навчальних годин (в межах виділеного МОН обсягу) для «підтримки» певних, як правило випускаючих, кафедр. 3 цією ж метою встановлюються такі форми контролю опанування знань для відповідних дисциплін, як звичайний залік замість іспиту або диференційованого заліку (для складання яких студенту дійсно приходиться ретельно вивчати матеріал курсу). Такий стан справ призводить до формалізації вивчення дисциплін, що неминуче позначається на рівні знань майбутнього фахівця 3 питань охорони праці і взагалі зневажливому ставленні в подальшому до цих питань (що, загалом і підтверджується наведеними вище статистичними даними).

Окрім того, останнім часом у певних ЗВО України намітилася тенденція щодо виводу дисциплін з охорони праці та цивільного захисту у розряд вибіркових. Такий стан справ, на тлі існуючого загального зневажливого ставлення до зазначених дисциплін, може призвести до того, що вони взагалі зникнуть 3 програм підготовки майбутніх фахівців. В свою чергу галузі народного господарства отримують спеціалістів, які й гадки не мають про те, яким чином забезпечувати власну i колективну безпеку в рамках виробничих процесів. Наслідком цього неминуче стане стрибок підвищення кількості нещасних випадків, професійних захворювань, а також промислових аварій та катастроф.

Друга проблема полягає в тому, що більшість стандартів освіти взагалі не містять жодної компетенції з питань охорони праці та безпеки життєдіяльності (рис. 4). 


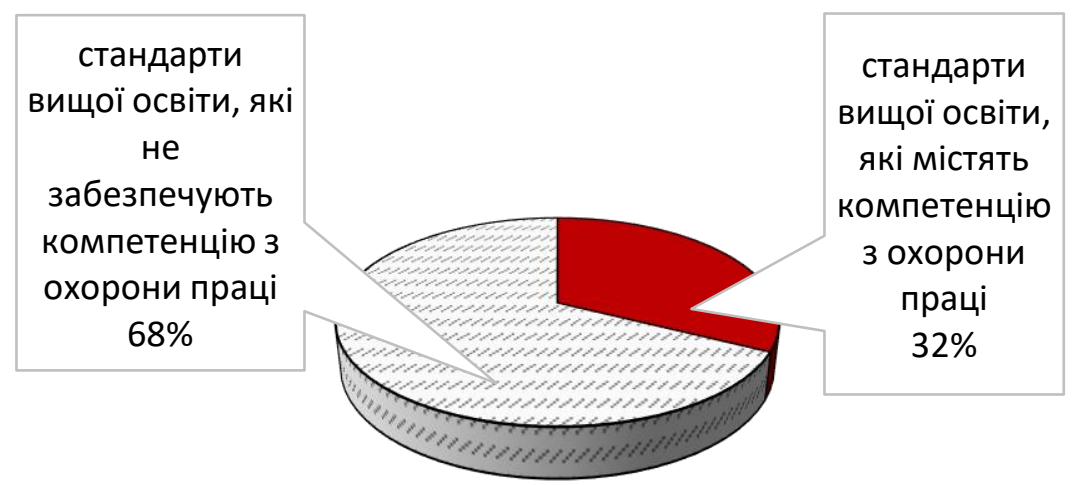

Мал. 4 - Питома вага наявності спеціальних «безпекових» компетенцій у стандартах вищої освіти України

В такому разі виникає питання, яким чином людина в умовах виробництва буде забезпечувати власну та колективну безпеку, не маючи для цього навіть початкових знань? А, зважаючи на те, що фахівці з вищою освітою, $\epsilon$ кадровим управлінським резервом країни, яким чином вони будуть виконувати, наприклад, вимоги Закону України «Про охорону праці», зокрема щодо забезпечення комфортних, здорових та безпечних умов праці? І яким чином опікуватися, наприклад, питаннями пожежної безпеки у закладах освіти, якщо майбутні працівники освіти не вивчають цих питань або вивчають їх формально? I чи варто дивуватися в такому випадку тенденціям до зростання загибелі людей від наслідків пожеж у закладах освіти? Нажаль, ці питання поки що залишаються відкритими, хоча наведені вище статистичні дані (щодо тенденцій зростання кількості нещасних випадків, пов'язаних 3 організаційними причинами) підтверджують їх актуальність, серйозність та нагальність вирішення.

Третя проблема полягає в тому, що для певних спеціальностей взагалі на сьогоднішній день відсутні стандарти освіти (рис. 5). Таким чином перелічені вище проблеми актуальні і для них.

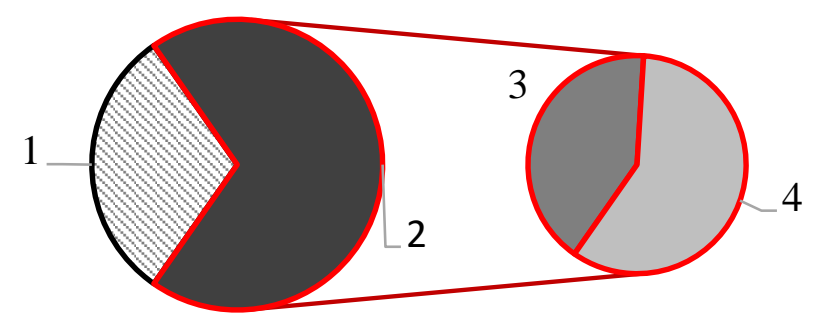

Мал. 5 - Питома вага забезпечення стандартами вищої освіти спеціальностей в Україні:

1-кількість спеціальностей, для яких стандарти вищої освіти відсутні (44\%); 2-кількість спеціальностей, для яких затверджені стандарти вищої освіти (66\%); 3-кількість спеціальностей, для яких стандартами вищої освіти передбачено компетенцію з охорони праці (41,25\%); 4-кількість спеціальностей, для яких у стандартах вищої освіти не передбачено компетенцію з охорони праці (58,75\%)

Виходячи з визначених проблем системи підготовки майбутніх фахівців з питань охорони праці у закладах освіти України можна запропонувати наступні шляхи їх вирішення, які дозволять в подальшому підвищити рівень безпеки та культури праці на підприємствах.

Перший 3 них полягає у необхідності поновлення чинності наказу № 969/922/216, який дозволить конкретизувати вимоги 
компетентності «здійснення безпечної діяльності» для стандартів освіти за принципом «від загального до конкретного», послідовним вивченням дисциплін «Безпека життєдіяльності» - «Основи охорони праці» «Охорона праці в галузі» (Bochkovskyi A. Р., Sapozhnikova N.Yu., 2019, №6, pp. 95-106; Bochkovskyi A. P., Sapozhnikova N.Yu., 2019, № 1 (73). pp. 10 - 14.). Слід зазначити, що перелік наведених дисциплін надано лише як приклад порядку опанування знань майбутніми фахівцями та потребує перегляду і доповнення, відповідно до існуючої Концепції реформування системи управління охороною праці в Україні. Це, зокрема, передбачає розробку нових типових програм, метою яких $\epsilon$ набуття студентами компетенцій щодо управління охороною праці на основі проактивного підходу (прогнозування та попередження виникнення професійних небезпек) Другий шлях полягає у необхідності підвищення якості засвоєння знань та викладання дисциплін 3 охорони праці. Підвищення якості засвоєння знань передбачає розробку науково-обґрунтованого підходу до встановлення кількості навчальних годин на опанування визначеного обсягу навчального матеріалу. Слід зазначити, що на сьогоднішній день (як і раніше), встановлення кількості навчальних годин для набуття знань з охорони праці відбувається виключно на суб'єктивній основі.

Так, наприклад, згідно 3 наказом №969/922/216, для вивчення відповідних дисциплін встановлювався обсяг навчальних годин з розрахунку не менш ніж 54 години. A, згідно з вимогами НПАОП 0.00-4.12-05, для вивчення теоретичної частини питань 3 охорони праці відводилося лише 30 годин. В той самий час для перепідготовки та підвищення кваліфікації працівників відводиться не менше 15 годин. Теоретична частина предмета «охорона праці» під час професійної підготовки працівників для виконання робіт, які не належать до переліку робіт з підвищеною небезпекою, вивчається в обсязі не менше 10 годин, а під час перепідготовки та підвищення кваліфікації - не менше 8 годин» (Bochkovskyi A. P., Sapozhnikova N.Yu., 2019, №6, pp. 95-106).

$€$ очевидним, що існуючий суб'єктивний підхід до встановлення обсягу навчальних годин $є$ за своєю суттю формальним та потребує перегляду. В такому випадку вирішення зазначеної проблеми знаходиться у площині встановлення об'єктивних залежностей між якісними характеристиками навчального матеріалу та психофізіологічними можливостями людини до його засвоєння протягом певного часу. Це $\epsilon$ складною проблемою, яка потребує розробки певних математичних моделей на основі положень відомих психофізіологічних законів (ВебераФехнера та інших) (Bochkovskyi A. Р., Sapozhnikova N.Yu., 2019, №6, pp. 95-106).

Не менш актуальною $€$ проблема підвищення якості викладання дисциплін 3 охорони праці. Не $\epsilon$ секретом, що професорсько-викладацький склад профільних кафедр багатьох ЗВО України за рівнем своєї кваліфікації (щодо освітньої або наукової спеціальності) не відноситься до спеціалістів 3 питань охорони праці. В такому випадку МОН та керівництву ЗВО слід встановити чіткі критерії відповідності викладача профілю кафедри і дисциплінам, які він викладає. Адже існуючі характеристики відповідності кваліфікації викладача за видами і результатами професійної діяльності (згідно 3 «Ліцензійними умовами провадження освітньої діяльності») не можна вважати об'єктивними. Це можна стверджувати 3 огляду на те, що, по-перше, жоден з пунктів не передбачає наявності у викладача профільної освіти з охорони праці або наукового ступеня зі спеціальності 05.26.01 - охорона праці, а подруге, не містить умови відповідності тематики наявних наукових праць викладача профілю кафедри (Ліцензійні умови провадження освітньої діяльності). Впорядкування спеціальності викладачів профілю кафедр $\epsilon$ обов'язковою умовою підвищення якості освіти не тільки з питань охорони праці, а й 3 інших дисциплін.

I на решті, третій шлях полягає у негайному забезпеченні всіх без виключення спеціальностей стандартами освіти, в рамках 
яких буде враховано вимоги наказу №969/922/216.

Проблема підвищення рівня мотивації працівників та керівників підприємств до неухильного виконання вимог з охорони праці теж $€$ достатньо складною, а ії вирішення передбачає насамперед зміну концепції соціального страхування в Україні. Тобто перехід системи соціального страхування від нещасних випадків та професійних захворювань на підприємствах від існуючої концепції сплати єдиного соціального внеску до концепції диференційованого підходу сплати такого внеску відносно рівня ризику виникнення професійних небезпек по кожному робочому місцю. Тобто, чим більш $\epsilon$ небезпечним підприємство і чим більш $\epsilon$ небезпечними чи шкідливими умови праці по кожному робочому місцю, тим більшими повинні бути відрахування коштів підприємством до Фонду соціального страхування.

Така концепція $\epsilon$ прогресивною i існує в багатьох країнах світу, зокрема у країнах $€ C$ з найнижчими у світі показниками виробничого травматизму та профзахворювань (Бельгія, Франція, Германія, Фінляндія та інші). Про те у країнах, в яких система страхування базується, як і в Україні, на відрахуванні єдиних внесків (Індія, Філіппіни, В’єтнам та деякі інші) спостерігаються найвищі у світі відповідні показники. Згідно з висновками МОТ, диференційований підхід, в питаннях соціального страхування, сприяє розвитку профілактичних заходів на підприємствах щодо запобігання виникненню нещасних випадків та профзахворювань. Такі профілактичні заходи дозволяють скоротити компенсаційні витрати підприємства по виплатах постраждалим та отримати прибуток в 1,6 євро на кожний вкладений євро (Усиление роли программ страхования в предотвращении несчастных случаев на производстве и профессиональной заболеваемости). Слід зазначити, що на сьогоднішній день у світі близько $60 \%$ загального обсягу соціального страхування відбувається в рамках диференційованого визначення розміру страхових внесків, що підкреслює ефективність зазначеної системи страхування.

Основною проблемою впровадження зазначеної системи та ефективності їі функціонування $€$ відсутність математичних моделей (Бочковський А. П., дис., 2019; Bochkovskii A.P., Gogunskii V.D., 2018; Bochkovskyi А. Р., 2018), що дозволяють встановлювати об'єктивні залежності між рівнем професійного ризику та розміром страхового внеску з урахуванням випадкового характеру впливу на працівника у часі небезпечних та шкідливих виробничих факторів. Для встановлення зазначених залежностей можна запропонувати застосовувати оптимізаційну математичну модель, що дозволяє розглядати випадки нанесення шкоди здоров'ю працівника сукупним та окремим впливом негативних виробничих факторів:

$$
\sum_{i=1}^{n}\left[\mathrm{H}_{i}+p_{i} M \Delta_{i}\right] \leq \Phi,
$$

де $H_{\mathrm{i}}$ - ресурси на мінімізацію впливу $\mathrm{n}$ видів негативних виробничих факторів, $p_{\mathrm{i}}-$ вартість ліквідації одиниці наслідків реалізації професійного ризику у небезпеку, Ф-величина розміру фінансових ресурсів суб'єкта господарювання на охорону праці працівника протягом часу Т, $M \Delta_{i}=g_{i}\left(h_{i}+H_{i}\right)^{-j_{i}}$, gi, jiдані, які визначаються шляхом обробки статистичних даних щодо фактичних перевищень гранично-допустимих концентрацій (рівнів) при відповідних витратах, що виділені на захисні заходи.

В цьому випадку необхідно порівнювати величину $\sum_{i=1}^{n} k_{i} M \Delta_{i}$, що може бути отримана в результаті вирішення (1) з розміром страхової премії, де $k_{\mathrm{i}}$ - величина гранично-допустимої концентрації (рівня) і - того негативного фактора.

Основою розробки наведеної моделі $\epsilon$ оптимізаційна модель планування управління професійними ризиками, апробацію якої було проведено у Фонді соціального страхування України (Бочковський А. П., дис., 2019). 


\section{Висновки}

1. Проведений аналіз статистичних даних за 2007 - 2019 роки показав, що за період з 2010 року по 2014 рік (період дії наказу № 969/922/216) кількість нещасних випадків за організаційними причинами знизилась на 16,3\%. При цьому, найбільш активне зниження спостерігалося за період з 2011 по 2012 роки (на 10\%), що є цілком природньо. За період 3 2007 по 2011 роки (до введення в дію наказу), а також за період з 2014 по 2019 роки (скасування дії наказу), аналогічні показники зросли на 2,5\% та 3,1\% відповідно. При цьому, в структурі організаційних причин за період 2014 - 2019 років спостерігається стійка тенденція щодо зростання нещасних випадків, які пов'язані 3 невиконанням інструкцій 3 охорони праці (на 5,4\% тільки за останні три роки). За період з 2011 по 2014 роки відповідний показник на підприємствах України зменшився на 9,5\%. Результати аналізу свідчать про необхідність спрямування зусиль на реформування саме системи підготовки та навчання фахівців у 3 ВО з питань охорони праці та розробки заходів щодо посилення мотивації на підприємствах щодо неухильного виконання ними вимог нормативно-правових актів з охорони праці.

2. Основними проблемами системи підготовки фахівців для будь-якої галузі 3 питань охорони праці у ЗВО України $\epsilon$ :

- загальний характер змісту та суті існуючої «безпекової» компетентності (з охорони праці) у стандартах освіти, що призводить до формалізації процесу навчання студентів 3 питань охорони праці за рахунок злиття різнопланових дисциплін, зменшення навчальних годин на їх опанування, зміни форм контролю знань студентів з іспиту на залік, а також виведення відповідних дисциплін у розряд вибіркових, наслідком чого $є$ процес їх фактичного знищення;
- відсутність «безпекової» компетенції у 68\% стандартах освіти;

- відсутність стандартів освіти для 44\% спеціальностей підготовки майбутніх фахівців;

- відсутність "Охорони праці», як окремої спеціальності (для можливості підготовки профільних спеціалістів для галузей народного господарства).

3. Основними шляхами підвищення рівня культури праці в Україні є:

- поновлення чинності наказу № 969/922/216, який дозволить конкретизувати вимоги компетентності «здійснення безпечної діяльності» для стандартів освіти за принципом «від загального до конкретного»;

- розробка математичних моделей для встановлення об'єктивних залежностей між якісними характеристиками навчального матеріалу та психофізіологічними можливостями людини до його засвоєння протягом певного часу на основі положень відомих психофізіологічних законів;

- включення до характеристик відповідності кваліфікації викладача за видами і результатами професійної діяльності «Ліцензійних умов провадження освітньої діяльності» положення щодо обов'язкової відповідності профільної освіти або наукового ступеня та тематики наукових праць викладача профілю кафедри та дисциплін, які він викладає;

- забезпечення всіх без виключення спеціальностей стандартами освіти, в рамках яких буде враховано вимоги наказу №969/922/216;

- перехід системи соціального страхування України від існуючої концепції сплати єдиного соціального внеску до концепції диференційованого підходу сплати такого внеску відносно рівня ризику виникнення професійних небезпек по кожному робочому місці.

\section{Список використаних джерел}

Аналіз страхових нещасних випадків та професійних захворювань в Україні в 2007 2016 рр. Фонд соціального страхування від нещасних випадків на виробництві та професійних захворювань в Україні. URL: 
http://www.social.org.ua/activity/stat (дата звернення: 23.07.2020).

Бочковський А.П. «Людський фактор» та ризик виникнення небезпек: випадковість чи закономірність. Одеса, Юридична література, 2015. С. 136.

Бочковський А.П. Теоретичні аспекти універсалізації оцінки професійного ризику в системах управління охороною праці. Вісник Львівського державного університету безпеки життєдіяльності, 2016. № $14 . \quad$ C.134-151 DOI: 10.13140/RG.2.2.22043.87848

Бочковський А. П. Наукові основи управління ризиками виникнення професійних небезпек: дис. ... доктор техн. наук: спец. 05.26.01. НТУДП, Дніпро, 2019. 385 с.

Бочковський А.П., Сапожнікова Н.Ю. Підвищення ефективності функціонування системи управління охороною праці методами статистичного аналізу. Вісник Львівського державного університету безпеки життєдіяльності, 2017. №16. С. 84-99. URL: https://journal.Idubgd.edu.ua/ index.php/Visnuk/article/view/167 (дата звернення: 23.07.2020).

Гвоздій С.П. Теоретичні і методичні засади підготовки майбутніх фахівців соціономічних спеціальностей до безпеки житя і професійної діяльності: автореф. дис. ... доктор пед. наук; 13.00.04. Одеса, 2017. 46 с.

Закон України «Про охорону праці». URL: https://zakon.rada.gov.ua/laws/show/269412 (дата звернення: 24.07.2020).

Кобилянський О., Заюков І., Пінаєва О. Інформальна освіта в системі підвищення рівня промислової безпеки зайнятих громадян. Педагогіка безпеки, 2018. № 1. С. 21-28. URL: http://ir.lib.vntu.edu.ua/handle/ 123456789/25172 (дата звернення: 23.07.2020).

Ліцензійні умови провадження освітньої діяльності. URL: https://zakon.rada.gov.ua/ laws/show/1187-2015-\%D0\%BF (дата звернення: 24.03.2020).

Методичні рекомендації щодо розробки стандартів вищої освіти, 2019 р. URL: https://mon.gov.ua/ua/osvita/visha-osvita/ naukovo-metodichna-rada-ministerstva-osvitii-nauki-ukrayini/metodichni-rekomendaciyi-vo (дата звернення: 24.07.2020).

Наказ міністерства освіти і науки України, міністерства України з питань надзвичайних ситуацій та у справах захисту населення від наслідків чорнобильської катастрофи, державний комітет України з промислової безпеки, охорони праці та гірничого нагляду № 969/922/216 від 21.10.2010 p. URL: https://zakon.rada.gov.ua/rada/show/z105710 (дата звернення: 23.07.2020).

Профілактика виробничого травматизму та професійних захворювань за 2017-2019 рр. Фонд соціального страхування України. URL: http://www.fssu.gov.ua/fse/control/main/uk/ publish/category/919872 (дата звернення: 23.07.2020).

Поведа Т. П. Окремі тенденції щодо вивчення дисциплін безпекового циклу в умовах автономії вищих навчальних закладів України. Збірник наукових праць Кам'янецьПодільського національного університету імені Івана Огієнка. Серія педагогічна, 2017. № 23. C. 104-107 URL: http://journals.uran.ua/ index.php/2307-4507/article/view/125428/ 119883 (дата звернення: 24.07.2020).

Романюк Р. Я., Крюковська О.А. Щодо обов'язковості викладання дисциплін 3 охорони праці, безпеки житєдіяльності та цивільного захисту у вищих навчальних закладах. збірник наукових прачі Дніпровського державного технічного університету (технічні науки), 2019. Т.2, № 35. C. $121-126$ DOI: 10.31319/25192884.35.2019.57

Усиление роли программ страхования В предотвращении несчастных случаев на производстве и профессиональной заболеваемости. URL: https://www.ilo.org/ wcmsp5/groups/public/---europe/---rogeneva/---sro-moscow/ documents/publication/wcms_492746.pdf

Bochkovskyi A. P. Actualization of the scientific principles elaboration on evaluating the risks of occupational danger occurrence. Naukovyi 
Visnyk Natsionalnoho Hirnychoho Universytetu, 2018. № 6. pp. 95-103. DOI: 10.29202/nvngu/2018/14

Bochkovskii A.P., Gogunskii V.D. Development of the method for the optimal management of occupational risks. Eastern-European Journal of Enterprise Technologies, 2018. №3/3(93). pp. 6-13. DOI: 10.15587/1729-4061.2018.132596

Bochkovskyi A. P., Sapozhnikova. Promising direction for improving regulatory legal framework on labour protection for enterprises production food and beverages. Environmental safety and sustainable resources management, 2015. № 2 (12). pp. 85-93. DOI: 10.13140/RG.2.1.4156.3927

Bochkovskyi A. P., Sapozhnikova N.Yu. Minimization of the "human factor" influence in Occupational Health and Safety. Naukovyi Visnyk Natsionalnoho Hirnychoho Universytetu, 2019. № 6. pp. 95-106. DOI: 10.29202/nvngu/2019-6/14

Bochkovskyi A. P., Sapozhnikova N.Yu. Aspect of minimization areas of «Human factor» in labor safety. Grain Products and Mixed Fodder's, 2019. № 1 (73). pp. 10 - 14. DOI: 10.15673/gpmf.v19i1.1314

Bochkovskyi A. P., Sapozhnikova N. Yu., Gogunskii V. D. Labour protection and industrial safety in Ukraine: problems of transition period and perspective ways of development. Grain Products and Mixed Fodder's, 2016. №. 4 (64). $\begin{array}{llll}\text { pp. } \quad 42 & - & 50 . & \text { DOI: }\end{array}$ 10.13140/RG.2.2.20894.13126

Bochkovskyi A. P., Sapozhnikova N. Yu., Gogunskii V. D. Legal and organizational issues of improving the labor protection and industrial safety level at Ukrainian enterprises. Naukovyi Visnyk Natsionalnoho Hirnychoho Universytetu, 2017. № 5 (161). pp. 100-108. DOI: 10.13140/RG.2.2.33613.23528

Zhurbynskyi D., Tarasenko A. Культура безпеки як система знань та умова сталого розвитку суспільства. Вісник Львівського державного університету безпеки життєдіяльності, 2018. № $17 . \quad$ C. 47-52. DOI: $10.32447 / 20784643.17 .2018 .06$

\title{
Актуализация и пути повышения уровня культуры труда в Украине
}

\author{
Андрей Бочковский * А; Наталья Сапожникова А \\ *Corresponding author: д.т.н., доцент, профессор кафедры управления системами безопасности жизнедеятельности, е-таіl: \\ andrew.bochkovsky@gmail.com, ORCID: 0000-0002-4166-3148 \\ А Одесский национальный политехнический университет, проспект Шевченко, 1, г. Одесса, 65044, Украина
}

\begin{abstract}
Аннотация
Определено, что за период с 2010 года по 2014 год (период действия Приказа № 969/922/216) количество несчастных случаев, произошедших по организационным причинам (характеризуют уровень культуры труда) снизилось на 16,3\%. При этом, наиболее активное снижение наблюдалось в период с 2011 по 2012 года (на 10\%). За период с 2007 по 2011 годы (до введения в действие Приказа), а также за период с 2014 по 2019 годы (отмена действия Приказа), аналогические показатели возросли на 2,5\% и $3,1 \%$ соответственно, что свидетельствует про необходимость направления усилий на реформирование системы подготовки и обучения специалистов по вопросам охраны труда, а также разработку мероприятий по усилению мотивации предприятий к неукоснительному выполнению требований нормативно-правовых документов по охране труда. Основными проблемами системы подготовки будущих специалистов по вопросам охраны труда в ВУЗах Украины являются: общий характер содержания и сути существующей «безопасной» компетенции (по охране труда) в стандартах образования, что приводит к формализации процесса обучения студентов по вопросам охраны труда за счет объединения разноплановых дисциплин, уменьшения учебных часов на их усвоение, изменение форм контроля знаний студентов с экзамена на зачет, а также
\end{abstract}


выведение соответствующих дисциплин в разряд по выбору, последствием чего является процесс их фактического уничтожения; отсутствие «безопасной» компетенции в 68\% стандартов образования; отсутствие стандартов образования для 44\% специальностей подготовки будущих специалистов. Основными путями повышения уровня культуры труда в Украине являются: возобновление действия Приказа № 969/922/216, который позволит конкретизировать требования компетентности «осуществление безопасной деятельности» для стандартов образования по принципу «от общего к конкретному»; разработка математических моделей для установления объективных зависимостей между качественными характеристиками учебного материала и психофизиологическими возможностями человека к его усвоению в течении определенного времени на основе положений известных психофизиологических законов; включение в характеристики соответствия квалификации преподавателя по видам и результатам профессиональной деятельности (в соответствии с «Лицензионными требованиями производства образовательной деятельности») положения об обязательном соответствии профильного образования или научной степени и тематики научных работ преподавателя профилю кафедры и дисциплины, которые он преподает; обеспечение всех без исключения специальностей стандартами образования, в рамках которых будет учтено требования Приказа № 969/922/216; переход системы социального страхования Украины от существующей концепции уплаты единого социального взноса к концепции дифференцированного подхода уплаты такого взноса, в соответствии с уровнем риска возникновения профессиональных опасностей по каждому рабочему месту. Обосновано актуальность и разработано пути повышения уровня культуры труда в Украине. Результаты исследований будут использованы как аналитическая и теоретическая база для разработки научных основ минимизации проявлений «человеческого фактора» в сфере охраны труда.

Ключевые слова: охрана труда, культура труда, система образования, профессиональная опасность, «человеческий фактор».

\title{
Actualization and ways to improve of work culture in Ukraine
}

\author{
Andrii Bochkovckyi * A; Natalia Sapozhnikova A \\ *Corresponding author: A Odessa National Polytechnic University, 1, Shevchenko Ave, Odessa, 65044, Ukraine, Doctor of Technical Science (s), \\ Associate Professor, Professor Department of Systems Management Life Safety, e-mail: andrew.bochkovsky@gmail.com, ORCID: \\ http://orcid.org/0000-0002-4166-3148 \\ ${ }^{\text {A }}$ Odessa National Polytechnic University, 1, Shevchenko Ave, Odessa, 65044, Ukraine
}

\begin{abstract}
It is established that the number of accidents for organizational reasons (characterizing the level of the work culture) decreased by 16.3\% for the period from 2010 to 2014 (the period of validity of the Decree No. 969/922/216). In doing so, the most active decrease was observed for the period from 2011 to 2012 (by 10\%). For the period from 2007 to 2011 (before validity of the Decree), as well as for the period from 2014 to 2019 (after validity of the Decree), similar indicators increased by $2.5 \%$ and $3.1 \%$ respectively, indicating a need for aiming for reform the system of training and education of occupational health and safety experts and develop measures to motivation at enterprises to comply with the requirements of legal normative documents in the occupational health and safety obligatory. The main problems of the system of training of future occupational health and safety experts in universities of Ukraine are: the general nature of the content and essence of the existing "safety" competence (in the occupational health and safety field) in education standards leading to the formality of the training of students in the occupational health and safety field through convergence different disciplines, reducing the hours for their acquiring, changing forms of control of students' knowledge from examination to test, as well as moving of relevant disciplines in the choice
\end{abstract}


category, resulting in the process of their elimination; the lack of "safe" competence in $68 \%$ of education standards; the lack of education standards for $44 \%$ specialties of training of future experts. The main ways to improve of work culture in Ukraine are: update of Decree No. $969 / 922 / 216$, that will allow to concretize the requirements of the "safe activity" competence for the education standards on the principle "from the general to the specific"; development of mathematical models to determine of objective dependencies between qualitative characteristics of educational material and psycho-physiological abilities of a person to its acquiring during a certain time based on the provisions of known psychophysiological laws; inclusion in the characteristics of the teacher's qualification according to the types and results of professional activity of the "Licensed Conditions for Educational Activity" provisions concerning obligatory compliance the profile education or scientific degree and the subjects of scientific works of the teacher with the profile of the department and the disciplines that he teaches; providing educational standards to all specialties without exception, within which will take into account the requirements of Decree No. 969/922/216; transition of the social insurance system of Ukraine from the existing concept of payment of a unified social tax to the concept of a differentiated approach of payment of such tax in relation to the risk level of occupational dangers origin for each workplace. The actuality and the ways to improve of work culture in Ukraine are substantiated. The results of the research will be used as an analytical and theoretical basis for the development of scientific bases to minimize the "human factor" sign in the occupational health and safety field.

Keywords: occupational health and safety, work culture, education system, occupational danger, "human factor".

\section{References}

Analysis of accident and occupational disease in Ukraine in 2007-2016. Occupational accident and occupational disease insurance fund in Ukraine. URL: http://www.social.org.ua/ activity/stat (accessed: 23.07.2020).

Bochkovskyi A. P. (2015). "The "human factor" and the risk of hazard: coincidence or regularity. Yurydychna literature, 132.

Bochkovskyi A. P. (2016). "Theoretical aspects of univarsalization of professional risk evolution in occupational health and management systems». Bulletin of the Lviv State University of Life Safety, Vol. 14, pp. 134-151. DOI: 10.13140/RG.2.2.22043.87848

Bochkovskyi A. P. (2018). Actualization of the scientific principles elaboration on evaluating the risks of occupational danger occurrence. Naukovyi Visnyk Natsionalnoho Hirnychoho Universytetu, Vol. 6, pp. 95-103. DOI: 10.29202/nvngu/2018/14

Bochkovskyi A. P. (2019). "Scientific bases of management of risks of professional dangers". Thesis abstract of Dr.Sc.(Eng.). 05.26.01. Dnipro, Ukraine.
Bochkovskii A.P., Gogunskii V.D. (2018). Development of the method for the optimal management of occupational risks. EasternEuropean Journal of Enterprise Technologies, Vol. 3/3(93), pp. 6 - 13. DOI: 10.15587/17294061.2018.132596

Bochkovskyi A. P., Sapozhnikova. (2015). Promising direction for improving regulatory legal framework on labour protection for enterprises production food and beverages. Environmental safety and sustainable resources management, Vol. 2 (12), pp. 85-93. DOI: 10.13140/RG.2.1.4156.3927

Bochkovskii A. P, Sapozhnikova N. Yu. (2018). Improvement of the effectiveness of functioning of the occupational health and safety management system using statistical analysis. Bulletin of Lviv State University of Life Safety, Vol. 16, pp. 84-99. URL: https://journal. Idubgd.edu.ua/index.php/Visnuk/article/view/ 167 (accessed: 23.07.2020).

Bochkovskyi A. P., Sapozhnikova N.Yu. (2019). Minimization of the "human factor" influence in Occupational Health and Safety. Naukovyi 
Visnyk Natsionalnoho Hirnychoho

Universytetu, Vol. 6, pp. 95-106. DOI: https://doi.org/10.29202/nvngu/2019-6/14

Bochkovskyi A. P., Sapozhnikova N.Yu. (2019). Aspect of minimization areas of «Human factor» in labor safety. Grain Products and Mixed Fodder's, Vol. 1 (73), pp. 10 - 14. DOI: 10.15673/gpmf.v19i1.1314

Bochkovskyi A. P., Sapozhnikova N.Yu., Gogunskii V. D. (2016) Labour protection and industrial safety in Ukraine: problems of transition period and perspective ways of development. Grain Products and Mixed Fodder's, Vol. 4 (64), pp. 42 - 50 DOI: 10.13140/RG.2.2.20894.13126

Bochkovskyi A. P., Sapozhnikova N. Yu., Gogunskii V. D. (2017). Legal and organizational issues of improving the labor protection and industrial safety level at Ukrainian enterprises. Naukovyi Visnyk Natsionalnoho Hirnychoho Universytetu, Vol. 5 (161), pp. 100-108. DOI: 10.13140/RG.2.2.33613.23528

Guidelines for the Development of Higher Education Standards, 2019. URL: https://mon.gov.ua/ua/osvita/visha-osvita/ naukovo-metodichna-rada-ministerstva-osvitii-nauki-ukrayini/metodichni-rekomendaciyi-vo (accessed: 24.07.2020).

Gvozdij S.P. (2017). «Theoretical and methodological bases of preparation of future specialists of socio-economic specialties for safety of life and professional activity». Thesis abstract of Dr.Sc.(Ped.). 13.00.04. Odesa. 46 p.

Kobilyanskij O., Zayukov I., Pinayeva O. (2018). "Informal education in the system of raising the level of industrial safety of employed citizens». Pedagogika bezpeki, Vol. 1, pp. 2128. URL: http://ir.lib.vntu.edu.ua/handle/ $123456789 / 25172$

Law of Ukraine "On Occupational Safety". (2019). Available at: URL: https://zakon.rada.gov.ua/ laws/show/2694-12 (accessed: 24.07.2020).

Licensing Terms of Educational Activities. URL: https://zakon.rada.gov.ua/laws/show/11872015-\%D0\%BF (accessed: 24.07.2020).
Order of the Ministry of Education and Science of Ukraine, the Ministry of Ukraine for Emergency Situations and for the Protection of the Population from the Consequences of the Chernobyl Disaster, State Committee of Ukraine for Industrial Safety, Labor Protection and Mining Supervision No. 969/922/216 of 21.10.2010. URL: https://zakon.rada.gov.ua/ rada/show/z1057-10 (accessed: 23.07.2020).

Poveda T. P. (2017). «Separate tendencies for studying the disciplines of safety cycle in the conditions of autonomy of higher educational establishments of Ukraine». Zbirnik naukovih prac Kam'yanec-Podilskogo nacionalnogo universitetu imeni Ivana Ogiyenka. Seriya pedagogichna, Vol. 23, pp. 104-107. URL: http://journals.uran.ua/index.php/2307-4507 /article/view/125428/119883 (accessed: 24.07.2020).

Prevention of occupational injuries and occupational diseases for 2017-2019. Social Insurance Fund of Ukraine. URL: http://www.fssu.gov.ua/fse/control/main/uk/ publish/category/919872 (accessed: 23.07.2020).

Romanyuk R. Ya., Kryukovska O.A. (2019). «Obligatory teaching of occupational safety, life safety and civil protection disciplines in higher education». Zbirnik naukovih praci Dniprovskogo derzhavnogo tehnichnogo universitetu (tehnichni nauki), Vol. 2, Is. 35, pp. 121-126. DOI: 10.31319/2519-2884.35. 2019.57

Strengthening the role of employment injury schemes to help prevent occupational accidents and diseases. URL: https://www.ilo. org/wcmsp5/groups/public/---europe/---rogeneva/---sro-moscow/documents/ publication/wcms_492746.pdf

Zhurbynskyi D., Tarasenko A. (2018). «Culture of security as a system of knowledge and conditions of sustainable development of the society». Bulletin of Lviv State University of Life Safety, Vol. 17, pp. 47-52. DOI: 10.32447/20784643.17.2018.06. 